\title{
EL TEMA DEL DESARROLLO ECONÓMICO EN GRANDE SERTÃO: VEREDAS
}

\section{O TEMA DO DESENVOLVIMENTO ECONÔMICO EM GRANDE SERTÃO: VEREDAS}

\section{Francisco Zaragoza Zaldívar \\ Universidade Federal do Rio Grande do Norte}

RESUMO: En este artículo se analiza el tratamiento del tema del desarrollo económico en la novela Grande Sertão: Veredas, de João Guimarães Rosa. Se define el desarrollo como función del crecimiento económico, se enumeran los requisitos para el crecimiento y luego se constata cuáles de estos requisitos son abordados en la famosa novela brasileña.

PALAVRAS-CHAVE: Desarrollo económico. Crecimiento. Guimarães Rosa

\begin{abstract}
In this article we discuss how economic development is represented in the novel The Devil to Pay in the Backlands, by João Guimarães Rosa. Economic development is defined as a function of economic growth; the requirements for the growth are listed and we determine which of these requirements are included in the novel. KEYWORDS: Economic development. Growth. Guimarães Rosa
\end{abstract}

\footnotetext{
* Possui doutorado em Língua Espanhola e Literatura Espanhola e Hispano-Americana pela Universidade de São Paulo (2005). Atualmente é professor adjunto da Universidade Federal do Rio Grande do Norte. Natal, Rio Grande do Norte, Brasil. E-mail: professor.zaragoza@gmail.com
} 


\section{EL TEMA DEL DESARROLLO ECONÓMICO EN GRANDE SERTÃO: VEREDAS}

\section{FAUSTO Y LA TRAGEDIA DEL DESARROLLO}

En el libro Todo lo que es sólido se desvanece en el aire: la aventura de la modernidad, Marshall Berman interpreta detenidamente el Fausto de Goethe e identifica como característica predominante del héroe dramático una suerte de ímpetu vital al que denomina de deseo de desarrollo. Según el crítico norteamericano, lo que diferencia a Fausto de sus antecesores en la literatura es el hecho de que no desee para sí bienes ni riquezas, sino

un proceso dinámico que incluiría toda suerte de experiencias humanas, alegría y desgracia juntas, asimilándolas todas a su interminable crecimiento interior; incluso la destrucción de su propio yo sería parte integrante de su desarrollo."

(BERMAN, 1986, p. 41.)

Berman señala que uno de los grandes méritos culturales de Goethe es haber establecido una correlación entre el ideal cultural de autodesarrollo y el movimiento social efectivo hacia el desarrollo económico. Se trataría 
de dos fuerzas que se despliegan simultáneamente hasta terminar confundiéndose. Según Berman, Goethe da por sentado que la transformación del hombre moderno exige también la transformación de su mundo físico, social y moral. Es de aquí justamente que procede la heroicidad de Fausto como personaje: la liberación de inmensas energías reprimidas, el hecho de desatar oscuras fuerzas que producen un movimiento indetenible en el campo productivo, social e intelectual, tiene un elevado costo humano.

Berman analiza la historia de Fausto en su ensayo a través de tres metamorfosis: la primera es la del soñador; la segunda, la del amante; y la tercera, la del desarrollista. Es la tercera precisamente la que más nos interesa en el presente contexto. Tales metamorfosis sólo son posibles con la ayuda de Mefistófeles. Este aparece en la obra como el lado sombrío de toda creatividad, como su dimensión destructora. Su negatividad encarna la paradoja de que no se puede crear nada sin destruir al mismo tiempo. Pero además, como explica Berman, Mefistófeles no sólo expresa la necesidad de aceptar este hecho sin sentirse frenado por dudas morales, sino que también le proporciona a Fausto los medios necesarios para materializar sus ambiciones.

¿Cómo actuar, cómo avanzar libremente por la vía del autodesarrollo? La primera solución que el Mefistófeles goethiano le da a Fausto es apelar a la fuerza del dinero. Gracias a este, Fausto se hace física y espiritualmente libre de la comunidad en la que creció.

En un principio, los nuevos poderes de Fausto, asociados a su libertad individual, se manifestarán como poderes sexuales: "la vida erótica es la esfera en la que inicialmente él aprende a vivir y a actuar." (BERMAN, 1986, p. 52.) Este Fausto excitado, erotizado, va ganando poco a poco confianza en sí mismo hasta sentirse en condiciones de dejarse atraer y expresar su amor por el pequeño mundo del cual ha podido emanciparse, en particular por Margarita.

Sin embargo, a determinada altura, después de bien avanzada la trama, nuestro héroe encontrará una fórmula propia de autodesarrollo que lo hará independiente inclusive del auxilio del diablo.

Ahora, en su última encarnación, conecta sus derroteros personales con las fuerzas económicas, políticas y sociales que dirigen el mundo; aprende a construir 
y a destruir. Expande el horizonte de su ser, de la vida privada para la pública, de la intimidad para el activismo, de la comunión para la organización. Lanza todos sus poderes contra la naturaleza y la sociedad; lucha no sólo por cambiar su vida, sino la vida de todos. (BERMAN, p. 61.)

En esta fase final de sus metamorfosis, la del desarrollista, Fausto se subleva ante la presencia del mar, caudal de energía incesante. Mefistófeles le dice al héroe que los elementos de la naturaleza siempre han sido iguales, pero Fausto afirma encolerizado que es hora de rebelarse contra la naturaleza. Quiere dominarla; no soporta la idea de que toda la energía que el mar contiene pueda desperdiciarse sin obedecer a ningún propósito, sin una finalidad específica.

Comienza a librar entonces una batalla contra los elementos para someterlos a su albedrío. Su empresa será fructífera, arguye Berman,

porque se va a dirigir hacia la propia energía de la naturaleza y canalizarla para la obtención de combustible para nuevos proyectos y propósitos humanos, colectivos." (BERMAN, p. 61-62.)

Los sueños de Fausto darán paso así a programas concretos de desarrollo, planes para transformar la tierra y el océano.

Esboza grandes proyectos para encadenar al mar a propósitos humanos: puertos y canales hechos por la mano del hombre, donde se mueven embarcaciones repletas de hombres y de mercancías; represas para la irrigación en amplia escala; campos y bosques verdes, pastizales y jardines, una vasta e intensa agricultura; energía hidráulica para animar y dar sostén a las industrias emergentes; pujantes instalaciones, nuevas ciudades y villas por construir - y todo eso será creado a 
partir de una tierra desolada e improductiva, donde los seres humanos jamás soñaron vivir.

(BERMAN, 1986, p. 61.)

La búsqueda de sí mismo emprendida inicialmente por Fausto, su búsqueda por el autoconocimiento y el autodesarrollo, termina por desembocar en el esfuerzo titánico en pro del desarrollo económico. El nuevo poder adquirido por el héroe, que estriba fundamentalmente en el control sobre la fuerza de trabajo, le permitirá realizar la síntesis entre pensamiento y acción que tanto anhelaba: logrará usar la mente para transformar el mundo. La modernización del mundo material se convertirá en suma en una realización espiritual sublime.

Es precisamente por esto que Fausto, el desarrollista, es considerado por Berman un héroe moderno. Pero también por tal motivo, según el crítico, el héroe goethiano resulta inevitablemente trágico. Su tragedia deriva de su incapacidad para aceptar que junto con las nuevas posibilidades que se le abren al hombre con el desarrollo, surgen también nuevas realidades que imponen sacrificios humanos.

Esta tragedia se ve prefigurada en el conflicto entre la pareja de ancianos que forman Filemo y Baucia y Fausto. Los dos ancianos viven en el único pedazo de tierra idílico, cubierto de árboles y flores, que ha resistido a la embestida modernizadora organizada por Fausto. Fausto quiere apartarlos de allí para culminar su trabajo, para levantar en ese terreno una inmensa torre de observación. Trata de comprarlos, de cambiarlos de sitio, pero no lo logra. Entonces, en su primer acto deliberadamente malo, le dice a Mefistófeles que los quite del medio. Mefistófeles los asesina. Fausto, al saber que los ancianos han sido quemados vivos en su propia casa, protesta, como si no quisiera asumir su propia responsabilidad "sobre la muerte y el sufrimiento humano que abren el camino".

(BERMAN, 1986, p. 67.) 
Los dos ancianos asesinados representan los vestigios de lo mejor del mundo precapitalista al que la empresa de Fausto ha dado un golpe mortal. La belleza y la nobleza de Filemo y Baucia aterrorizan a Fausto porque materializan la posibilidad de la parálisis, de dejar de moverse, es decir, de morir. De modo trágico y a la vez irónico, al matar a la pareja, Fausto pronuncia su propia sentencia de muerte. Elimina lo que resta de su viejo mundo y ya no le queda más nada por hacer. Tan pronto como el desarrollista destruye el mundo premoderno, destruye su propia razón para existir. En otras palabras, en cuanto se libra de todos los obstáculos interpuestos en el camino, Fausto se ve a sí mismo en medio del camino, y sabe que debe ser apartado. Como todo sigue su curso y todo cambia, también él tendrá que ser sacrificado. La tragedia de Fausto, concluye Berman, es la tragedia del desarrollo por antonomasia.

\section{DESARROLLO ECONÓMICO Y CRECIMIENTO}

La fértil intuición de Goethe le permitió aprehender tempranamente la estrecha conexión que existe entre el desarrollo y el crecimiento económicos. Más o menos conscientes de las ideas del insigne dramaturgo alemán, los economistas y los historiadores económicos contemporáneos suelen consagrar dicho vínculo en la propia definición de desarrollo que presuponen en sus escritos o con la cual operan en la práctica.

De modo general, podemos afirmar que el desarrollo económico describe la capacidad que tiene una sociedad de pasar de una situación de escasez, producción exigua y pobreza a otra de más prosperidad, niveles de consumo más elevados y mejor calidad de vida. Dicho de otra manera, el desarrollo sería la capacidad de un país de crear riquezas y de mantener y mejorar el bienestar socioeconómico de su población, lo cual, como señala Krugman (1995) de modo sumamente sintético al referirse a la teoría de Hirschman sobre el desarrollo, supone la existencia de un círculo virtuoso económico. Un ingrediente esencial en la existencia del tal círculo virtuoso, como es lógico, lo constituye el crecimiento económico, que suele definirse como el aumento del producto o la renta de un país con el paso del tiempo, y normalmente se mide como 
el porcentaje o tasa de incremento anual del Producto Interior Bruto real per capita de una nación (SAMUELSON, 2012; MANKIW, 2009, p. 528).

No son pocos los historiadores que han manejado los conceptos de desarrollo y de crecimiento como equivalentes o intercambiables. Es el caso de Fernand Braudel (1996), quien, en el sexto y último capítulo del tercer volumen de su ya clásico estudio sobre los orígenes del Capitalismo, llama la atención sobre un fenómeno inédito que tiene lugar en la Inglaterra del siglo XVIII: se trata del crecimiento económico, fenómeno al cual no duda en calificar de revolucionario.

El célebre historiador francés enumera en su trabajo algunos de los desafíos que la economía inglesa tuvo que superar (o de los requisitos que hubo de satisfacer) para que se produjera el milagro del crecimiento, aparejados a la propia Revolución Industrial. Fueron estos el progreso agrícola, el crecimiento demográfico, la aplicación de la técnica a la producción, el boom de la industria algodonera, que despegó primero y arrastró consigo otros sectores, seguido por el boom de la industria del hierro, así como el triunfo del comercio de larga distancia, la multiplicación de los transportes internos, el incremento de la complejidad y la heterogeneidad de la división del trabajo, y por último, el triunfo del capital en sus más variadas formas: agrícola, industrial, comercial y financiero.

No por mera casualidad, opinamos nosotros, Braudel cita, entre las variadas causas del aumento del rendimiento agrícola inglés en el siglo XVIII, no solo el empleo de nuevas técnicas de explotación de los suelos y de rotación de los cultivos, sino, en particular, el surgimiento de un singular "círculo virtuoso" (el término de Krugman se hace eco del concepto de Braudel) entre la producción agrícola y la pecuaria. Se trata de lo siguiente: los excrementos del ganado, cada vez más abundante, servían de adobo para las plantas forrajeras con las que los animales eran alimentados. La mayor disponibilidad de pastos y forrajes que se derivaba de lo anterior, propiciaba a su vez el aumento de la población ganadera y de la producción de carne, lo cual incentivaba aún más la actividad agropecuaria, realimentando una y otra vez, en una espiral sucesiva, todo el proceso. De cierto modo la causa se convertía en consecuencia y la consecuencia en causa (BRAUDEL, 1996, p. 519).

Más recientemente, Spence (2011) menciona diversos factores o condiciones favorables al crecimiento económico que no difieren demasiado de 
los requisitos que enumera Braudel al explicar cómo se dio dicho fenómeno en la historia inglesa. Spence incluye en su relación de condiciones para el crecimiento la participación en el comercio global, explotando las ventajas comparativas de la nación; el aumento de la productividad mediante la innovación y la aplicación de la ciencia y la técnica a los procesos productivos; el ahorro y la inversión en bienes de capital y en recursos humanos, mediante políticas educacionales y el cuidado de la salud pública, así como mediante programas de inclusión social; la utilización de los incentivos de la economía de mercado. Pero de todos los requisitos tratados por este economista, uno en los que más énfasis hace, a fin de destacar su importancia, es la necesidad de que en el país que pretende desarrollarse haya un liderazgo, un consenso político y un marco institucional y legal adecuados que aseguren y propicien el crecimiento. "El trabajo de los líderes es, en parte, poner a todos dentro del mismo barco, construir un consenso por detrás de una visión del futuro, apoyada por una estrategia de crecimiento y desarrollo que sea confiable". (SPENCE, 2011, p. 26-27.)

Es la ausencia o presencia de las condiciones arriba citadas, en última instancia, la que impulsará u obstaculizará el crecimiento.

\section{RIOBALDO, EL DESARROLLISTA}

No hay dudas de que Riobaldo, el protagonista y narrador de Grande Sertão: Veredas, es un héroe de filiación fáustica. Su tentativa de pacto con el diablo permite afirmarlo con tranquilidad. Pero, en ese mismo sentido, constituye una evidencia de no menor importancia el hecho de que Riobaldo lleve adelante un programa modernizador, un proyecto de desarrollo, en buena medida similar al del trágico héroe de Goethe.

¿En qué consiste dicho programa? Formulado de un modo un tanto esquemático, consiste en eliminar el desorden que reina en el sertão, desorden representado por la violencia arbitraria de los bandos de jagunços, quienes tienen a la región sumida en un estado de guerra civil permanente, con el fin de favorecer la implantación de las relaciones de trabajo capitalista en el interior del país y de promover el crecimiento económico. 
En otras palabras, se trata de crear un marco institucional y sociopolítico adecuado para el crecimiento, requisito, como ya vimos, ampliamente resaltado por Spence (2011).

Este programa, en realidad, es heredado en parte por Riobaldo de Zé Bebelo, su antiguo jefe. Zé Bebelo insiste en varias ocasiones en la novela en que es necesario acabar con la locura que impera "nos Gerais" e imponer el respeto y la obediencia a la Ley. Hay que eliminar el bandolerismo y las prácticas políticas tradicionales y localistas -la tradición del Coronelismoque impiden la unidad nacional bajo un poder centralizado. Leamos las reflexiones de condena del personaje de la actitud de los jagunços.

"Sei seja de se anuir que sempre haja vergonheira de jagunços, a sobre-corja? Deixa, que, daqui a uns meses, neste nosso Norte não se vai ver mais um qualquer chefe encomendar para as eleições as turmas de sacripantes, desentrando da justiça, só para tudo destruírem, do civilizado e legal?"' Assim dizendo, na verdade sentava o dizer, com ira razoável. A gente devia mesmo reprovar os usos de bando em arma invadir cidades, arrasar o comércio, saquear na sebaça, barrear com estrumes humanos as paredes da casa do juiz-de-direito, escramuçar o promotor amontado à força numa má égua, de cara para trás, com lata amarrada na cauda, e ainda a cambada dando morras e aí soltando os foguetes! Até não arrombava, pipas de cachaça diante da igreja, ou isso de se expor padre sacerdote nu no olho da rua, e ofender as donzelas e as famílias, gozar senhoras casadas, por muitos homens, o marido obrigado a ver?

(ROSA, 1995, p. 88.)

Al mismo tiempo, además de proponerse la instauración de un marco legal favorable al desarrollo, el programa de Zé Bebelo se manifiesta como una promesa utópica, anunciando el progreso de las regiones del interior del 
Norte de Brasil. Riobaldo, rememorando la época en que había conocido a Zé Bebelo, resume las ideas del viejo jefe en una frase:

Dizendo, que, depois, estável que abolisse o jaguncismo, e deputado fosse, então reluzia perfeito o Norte, botando pontes, baseando fábricas, remediando a saúde de todos, preenchendo a pobreza, estreando mil escolas.

(ROSA, 1995, p. 89.)

Como podemos comprobar en la cita, se mencionan otra vez en conjunto varias de las condiciones o de los requisitos para el crecimiento ya relacionados por Braudel y por Spencer, a saber, la construcción de vías de comunicación que faciliten el transporte y el comercio y la formación de un mercado nacional; la inversión en bienes de capital, como fábricas e industrias, que permitan el incremento de la productividad y del producto total de la nación o, en otras palabras, se propone recurrir a la industrialización como estrategia de combate a la pobreza; por último, la inversión en recursos humanos, bajo la forma de gastos con salud pública y educación.

Zé Bebelo, sin embargo, no tiene éxito en la ejecución de su proyecto. Acaso esto incida en que sea reemplazado en su puesto de líder por Riobaldo, quien apela al expediente del pacto con el diablo para tomar el poder. Así, será Riobaldo a fin de cuentas el que logre materializar el programa desarrollista de Zé Bebelo.

Para conseguirlo, son esenciales dos decisiones que toma el héroe a lo largo de la obra. Primero, establecer una alianza con las fuerzas del capitalismo, representadas en cierto modo en la novela por los personajes de seô Habão y seo Ornelas. Segundo, reclutar un ejército popular -el ejército de los catrumanos-, movido por el resentimiento y el deseo de ascenso social, con el cual resulta posible barrer los bandos de jagunços opuestos a la Ley, bandos comandados por Hermógenes, el asesino de Joca Ramiro.

Veamos de forma más detallada ambas decisiones.

Es significativo que cuando se produce el primer encuentro entre el dueño de la hacienda $O$ Valado, seô Habão, y los hombres de Zé Bebelo, 
la visión del terrateniente le cause un raro malestar a Riobaldo. No es de la misma naturaleza que el odio que este siente por Hermógenes, pero en cualquier caso, el narrador afirma: "Eu, digo-me disse: que um homem assim, seô Habão, era para se querer longe da gente; ou, pois, então, que logo se exigisse e deportasse." (ROSA, 1995, p. 264.)

La figura del hacendado le desagrada y a la vez le llama la atención a Riobaldo. Este termina por darse cuenta de que su curiosidad nace de la condición tan diferente a la suya que tiene aquel hombre. Si los jagunços responden a una mentalidad heroica, en la cual las proezas bélicas y la proximidad de la muerte tienen un alto significado, la mentalidad de sêo Habão sólo se detiene sobre lo trivial. Su visión de la realidad es abstracta, utilitaria y calculadora.

Zé Bebelo, quien inicia un diálogo con el hacendado tratando de realzar sus propias virtudes como jefe, "Zé Bebelo aos poucos mais proseava, com ensejos de ir mostrando a valia declarada que tinha, de jagunço chefe famoso", se ve poco a poco arrastrado por los temas de conversación que impone seô Habão. "Porque seô Habão, mansoso e manso, sem glória nenhuma, era um toco de pau, que não destorce, fincado sempre para seu arrumo. Ele só entendia de assuntos triviais, mas cuidava deles com uma força vagarosa, verdadeira, de boi-de-coice." (ROSA, 1995, p. 264.)

Ante este espíritu que solamente "dava balanço, inquiria, e espiava gerente para tudo, como se até do céu, e do vento suão, homem carecesse de cuidar comercial", todos los valores se anulan, se igualan, se reducen a mercancía, a mero valor de cambio. Lo que no sea útil, no se pueda sujetar a la ley de la equivalencia económica, no sea, en suma, un negocio, no despierta su interés. Por eso a sus ojos las proezas de los jagunços no tienen ningún significado: "no mais, nem ouvia, apesar de toda a cortesia de respeito, quando se falava em Joca Ramiro, no Hermógenes e no Ricardão, em tiroteios com os praças e na grande tomada, por quinhentos cavaleiros, da formosa cidade de São Francisco." (ROSA, 1995, p. 264.)

Riobaldo intuye que una mente así desconoce la dignidad de la persona, su singularidad, desconoce la belleza y lo particular de este mundo. Ante su lógica utilitarista, los “passarinhos de Deus viram em má praga." (ROSA, 1995, p. 264.) Asimismo, la epidemia que azota al pueblo de Sucruiú no pasa en la opinión de tal hombre de un percance adverso que registrará como 
débito en su lista de pasivos al realizar el balance contable del año: "A bexiga do Sucruiú já terminou. Estou ciente dos que morreram: foram só dezoito pessoas...", afirma. (ROSA, 1995, p. 265.)

Riobaldo siente pena de los habitantes de Sucruiú cuando se entera de los planes que seô Habão les tiene reservados.

Disse que ia botar os do Sucruiú para o corte de cana e fazeçaõ de rapadura. Ao que a rapadura havia de ser para vender para eles do Sucruiú, mesmo, que depois pagavam com trabalhos redobrados. De ouvir ele acrescentar assim, com a mesma voz, sem calor nenhum, deu em mim, de repente, foram umas nervosias. Ao que, aqueles do Sucruiú, fossem juntas-de-bois em canga, criaturas de toda proteção apartadas.

(ROSA, 1995, p. 265.)

Para seô Habão, la mano de obra humana no difiere de la mano de obra animal. La falta de calor en la voz, la frialdad, es signo tal vez de la indiferencia de la lógica económica capitalista ante lo que no se refiera exclusivamente a la maximización de la ganancia. Sin embargo, a pesar del repudio a la situación imaginada por el hacendado, Riobaldo no se apresura a negar al otro: "Mas eu não tinha raiva desse seô Habão, juro ao senhor, que ele não era antipático." Riobaldo detecta incluso que seô Habão quiere usar a todos como fuerza de trabajo, hasta a los propios jagunços.

...espiou para mim, com aqueles olhos baçosos -aí eu entendi a gana dele: que nós, Zé Bebelo, eu, Diadorim, e todos os companheiros, que a gente pudesse dar os braços, para capinar e roçar, e colher, feito jornaleiros dele (...) Nem sei se ele sabia que ele queria. Acho que a idéia dele não arrumava o assunto assim à certa. Mas a naturezadele queria, precisava de todos como escravos.

(ROSA, 1995, p. 265.) 
Pero a pesar de darse cuenta de que seô Habão quisiera igualarlo a él y a sus compañeros a los habitantes de Sucruiú, quisiera esclavizarlos, subyugarlos como a los bueyes y a todas las bestias de trabajo, Riobaldo insiste en que "não tinha raiva desse seô Habão."

¿Por qué Riobaldo no se molesta? Nada menos que porque descubre en el modelo económico de seô Habão el elemento dinámico del capitalismo, la fuerza equivalente al oleaje del mar que Fausto usa como fuente de energía en sus proyectos. Poner a la gente de Sucruiú a producir raspadura; venderles la raspadura a ellos mismos y obligarlos a que paguen su consumo con más trabajo. Es este, en suma, el milagroso mecanismo de la explotación económica y del crecimiento. La plusvalía, la ganancia, como valorización del capital invertido, se deriva directamente de la explotación de la fuerza de trabajo. Pero también se deriva de dicho proceso el "círculo virtuoso" que está en la raíz de la espiral creciente en la cual el consumo estimula la producción y la producción, a su vez, estimula el consumo. Riobaldo ve, antes que nadie, que esta puede ser la máquina de tracción que desate todo el potencial de desarrollo del sertão. He aquí uno de los motivos por los que habrá de establecer una alianza con los representantes del capitalismo.

Para comprender de forma más clara dicha alianza, conviene analizar ahora otra escena en la que el tema sale de nuevo a flote. En este pasaje no aparece seô Habão, sino otro hacendado, seo Ornelas. Por el parentesco lejano que existe entre ambos personajes, podríamos considerarlos como equivalentes.

Seo Ornelas es ya un señor canoso, de edad avanzada, dueño de una hacienda grande. En cuanto Riobaldo lo encuentra, le solicita algunos caballos. Seo Ornelas acepta esta exigencia, que nos da una imagen arcaica de la práctica estatal del cobro de tributos. Después Riobaldo y sus hombres más importantes entran a la casa y se sientan a la mesa. Sin embargo, Riobaldo también hace entrar consigo al ciego Borromeu y a un niño negro llamado Guirigó. Hay algo en tal gesto de descortés, y de hecho Riobaldo pasa buena parte del tiempo que dura la cena comportándose de forma grosera con su anfitrión. A seo Ornelas no le agrada tener al ciego y al ladrón en su mesa: "Pelo tudo, era como se ele reprovasse minha decisão de trazer para 
a mesa semelhantes companhias. O menino e o cego Borromeu - aqueles olhos perguntados." (ROSA, 1995, p. 289)

Pero Riobaldo, deliberadamente, quiere que se note esta decisión, que el ciego y el niño no pasen desapercibidos. Su irreverencia señala hacia dónde se dirige su proyecto social: no se trata sólo de exigir la tributación y el apoyo económico de los hacendados al poder constituido; se trata de que estos dividan la mesa, sus recursos, con los excluidos.

¿Cómo ha de devolver el favor Riobaldo? ¿Cómo retribuirá a seô Habão y a seo Ornelas? Para comprender esto, hay que tener presente en primer lugar la magnitud de la amenaza que el estado de desorden y la regresión social suponen para la existencia de la propiedad privada. Veámoslo.

Cuando la tropa de Zé Bebelo llega por primera vez a O Valado, la hacienda de seô Habão, en el momento en el que la epidemia devasta al pueblo de Sucruiú, la imagen de la casa saqueada por los habitantes de la aldea vecina impresiona a Riobaldo.

Virgem! -digo ao senhor: o interior dela dava pena, nunca vi nada tão remexido e roubado. Total o que era de jeito de se carregar, o em arcas e em trouxas, e que no comum duma casa remediada se acha, faltava. Não se encontrou uma peça de roupa, uma lamparina de folha, uma folinha na parede (...) Tinham limpado a carne daquele costelame.(...) Com pouco mais uns dias que se passassem, o pessoal do Sucruiú era capaz de desmanchar até o prédio da casa, por seus esteios e caibros. (...) Sobravam só os passarinhos, soltos, como de toda parte no igual, que piaram assim uns momentos, pelo cabar da tardinha, alegres assim no empobrecido (ROSA, 1995, p. 254.)

La casa ha sido desmantelada y da la impresión de que, de durar un poco más el pillaje, el lugar volverá de nuevo a formar parte de la naturaleza. Es en este instante que Zé Bebelo y sus hombres capturan al negrito Guirigó, pequeño ladrón que encarna el robo por necesidad extrema. La escena es 
bastante divertida. Cuando Zé Bebelo le pregunta a Guirigó que qué buscaba en la casa, este responde que cosas de comer. Pero todos lo han visto vaciar el saco y caer en el suelo una alpargata y una lámpara. El personaje del negrito, que remite a sus congéneres en la picaresca, será tratado con cariño por Zé Bebelo, que exclama: "O que imponho é se educar e socorrer as infâncias deste sertão!” (ROSA, 1995, p. 254.)

Riobaldo también acogerá después al personaje y ordenará que vaya a su lado, como acompañante suyo, cuando forme su ejército. Tal adopción por parte de Riobaldo es muy significativa: expresa que sólo se puede garantizar el orden y la defensa de la propiedad si se les da abrigo y protección a estos desamparados. Y Riobaldo se lo hace entender a Seo Ornelas al tocar la cuestión en la mesa. Dirigiéndose a su anfitrión, exclama:

Duvidar, é só dar um saco vastoso na mão dele, e janela para pular, para dentro e para fora: capaz de supilar os recheios e pertences todos duma casa-grande de fazenda, feito esta, salvo que seja...

(ROSA, 1995, p. 289.)

De no hacerlo así, de no sentarlo a la mesa, de no dividir el pan con el ciego y el pobre, todo podría ser peor, mucho peor.

Vayamos ahora a la segunda decisión de Riobaldo, la de formar un ejército popular que lo ayude a restaurar el orden, con el fin, entre otros, de garantizar el crecimiento. La soldadesca de su nuevo ejército proviene de los lugares más remotos del interior "dos Gerais", donde habitan los catrumanos.

En efecto, el primer encuentro de los hombres de Zé Bebelo -entre los cuales está Riobaldo- con los catrumanos, se da en el pueblo de Pubo. Este es uno de los momentos decisivos de la novela de Guimarães Rosa. A tal altura de la historia, Zé Bebelo está desorientado, se ha perdido, y acaba por arribar a uno de los lugares más distantes del sertão, uno de sus confines, lugar "fundo, fundo".

Riobaldo relata este episodio del que es testigo directo. Avanzando por un camino en el que se encuentran frecuentes señales que prohíben el paso, en compañía de otros dos caballeros, Nelson y Acauã, Riobaldo se topa con 
varios hombres armados. Estos hombres tienen una apariencia rarísima. Están prácticamente desnudos, "quase que não possuíam o respeito de roupas de vestir” (ROSA, 1995, p. 245) y uno lleva sólo una tanga y un chaleco puestos, una combinación que mueve a risa. El aspecto físico de todos ellos no es menos raro y desagradable: uno tiene la barba muy poblada, como si no supiera o no pudiera afeitarse; otro muestra la boca estropeada, dividida en tres, lo que nos sugiere que tiene labios leporinos; aunque son de tez oscura, la mayoría tiene la piel cetrina de tanto alimentarse con raíces de burití; están, además, borrachos, y para colmo tienen piojos. Por si fuera poco, las armas que usan son también insólitas: trabucos, bacamartes, lazarinas, todas viejas, del siglo XIX. En esta primera parte de la escena del encuentro, vemos una superposición incesante de signos de incultura y de atraso: pobreza en el vestir, insalubridad, desnutrición, miseria. Los hombres que les obstruyen el paso a Riobaldo y los suyos parecen estar tan fuera de lugar, que Riobaldo afirma: "Para o nosso juízo, eles eram doidos." (ROSA, 1995, p. 245)

¿Cómo podrían estos hombres dedicarse a ser salteadores?, se pregunta Riobaldo. Acauã explica que en realidad no son salteadores, sino habitantes de aquella región, "homens reperdidos sem salvação naquele recanto lontão de mundo, groteiros dum sertão, os catrumanos daquelas brenhas." (ROSA, 1995). Viven en cuevas, en las cavidades que se forman en las paredes de las orillas de los ríos, y a semejanza de los animales, dan a luz a sus hijos en estas grutas, "dando crias feito bichos, em socavas." A Riobaldo le parecen tan menesterosos, que inicialmente siente por ellos un sentimiento de piedad. “Tanteei pena deles, grande pena." (ROSA, 1995, p. 246)

Poco después llega toda la tropa de Zé Bebelo al punto en el que los catrumanos les cortan el paso a Riobaldo y a sus dos compañeros. Zé Bebelo le presta escasa atención a lo que estos hombres le dicen. El aspecto miserable, la pobreza que revelan sus rostros desdentados y los harapos que usan, así como el atavismo que delatan sus armas y las monedas de la época colonial que todavía conservan, no le permiten tomárselos en serio. Las adversidades y la escasez golpean a estos hombres con tanta fuerza, que las costumbres civilizadas son en ellos la imagen de una práctica remota que a duras penas logran imitar, un remedo rústico. Precisamente la dificultad en la imitación de las formas de comportamiento civilizado 
-ya sea en los gestos de urbanidad y cortesía (como la entrega de una moneda de plata a Zé Bebelo), sea en los usos lingüísticos cultos- los cubre de ridículo y provoca risa. Para evitar reírse, casi por caridad, Zé Bebelo contrae el rostro y frunce el ceño.

Pero Riobaldo no tiene ganas de reír en lo absoluto al presenciar la escena. "Mas eu não ri. Ah, daí, não ri honesto nunca mais, em minha vida." (ROSA, 1995, p. 248) Pues resulta que después de verse embargado por la piedad, pasa paulatinamente a un estado de profundo pavor. Y es que mientras más evidente se le hace la condición animal de los catrumanos, más justificado le parece el hecho de temerles ["Que aqueles homens, eu pensei: que nem mansas feras; isto é, que no comum tinham medo pessoal de tudo neste mundo." (ROSA, 1995)]

El propio narrador Riobaldo da una explicación a este miedo en su relato. En la condición semibestial de los catrumanos, el héroe intuye de pronto la presencia de una energía de inmenso poder destructivo.

Raça daqueles homens era diverseada distante, cujos modos e usos, mal ensinada. Esses, mesmo no trivial, tinham uma capacidade para um ódio tão grosso, de muito alcance, que não custava quase que esforço nenhum deles; e isso com os poderes da pobreza inteira e apartada. (ROSA, 1995, p. 248)

El centro de esa energía radica en un profundo sentimiento de odio, y su causa visible es la pobreza. A fuerza de tanto carecer, los catrumanos se han vuelto fieras, los sentimientos humanos más loables han ido menguando en ellos. Bloquean el camino porque no quieren que los habitantes del poblado de Sucruiú circulen por allí y les traigan la enfermedad que los asola. Ante el terror del contagio, desconocen la caridad y el socorro. Riobaldo piensa incluso que si lo hubieran atrapado solo, los catrumanos lo habrían matado sin conmiseración ninguna.

...que se eles tivessem me pegado sozinho, eu apeado e precisado, decerto me matavam, para roubar minhas 
armas, as coisas e minhas roupas. Amargo que acabavam comigo, sem escrúpulos, hom'essa, que nem tinham, porquanto eu era desconhecido e forasteiro. De doente, ou ferido perdendo meu sangue, que eu estivesse, algum deles ia ser capaz de me ceder gole duma cuia d'agua?

(ROSA, 1995, p. 249)

La falta de humanidad, de respeto a la vida del hombre, no carece de cierta lógica. Los catrumanos parecen haber retrocedido al estado de naturaleza y a las formas de vida salvaje del hombre primitivo o de la sociedad animal. Bajo esta condición, es mínimo el control que sobre ellos ejercen las prohibiciones y las normas que instituye la vida civilizada. Desconocen la piedad, la solidaridad, la hospitalidad con los forasteros. Sin embargo, este odio tiene otra causa menos visible, y no se deriva directamente de los imperativos de la lucha por la sobrevivencia ni de un placer ante la violencia de carácter instintivo.

Se trata de algo más sutil, de una expresión de hostilidad contra la cultura y contra el conjunto de normas que justifica las diferencias sociales, entendidas específicamente como diferencias en la adquisición y el reparto de los bienes económicos entre los hombres.

De homem que não possui nenhum poder nenhum, dinheiro nenhum, o senhor tenha todo medo! O que mais digo: convém nunca a gente entrar no meio de pessoas muito diferentes da gente!

(ROSA, 1995, p. 248.)

Como obedeciendo a la ley física de la diferencia de potencial, Riobaldo siente que el potencial del odio es mayor cuanto más acentuadas son las desigualdades sociales. Para el que está en la posición privilegiada, este sentimiento sólo puede ser visto como una tremenda amenaza. Si las frágiles ataduras que mantienen a los catrumanos olvidados en su comarca se desamarrasen, y a la vez el número de estos hombres se multiplicase, aflo- 
raría un torrente incontenible que arrasaría con las bases de la sociedad y modificaría su estructura.

E de repente aqueles homens podiam ser montão, montoeira, aos milhares mis e centos milhentos, vinham se desentocando e formando, do brenhal, enchiam os caminhos todos, tomavam conta das cidades. Como é que iam saber ter poder de serem bons, com regra e conformidade, mesmo que quisessem ser? Nem achavam capacidade disso. Haviam de querer usufruir depressa de todas as coisas boas que vissem, haviam de uivar e desatinar. Ah, e bebiam, seguro que bebiam as cachaças inteirinhas da Januária. E pegavam as mulheres, e puxavam para as ruas, com pouco nem se tinha mais rua, nem roupinhas de meninos, nem casas. Era preciso mandar tocar os sinos das igrejas, urgência implorando de Deus o socorro. E adiantava? (...)

Aí foi que eu pensei o inferno feio deste mundo: que nele não se pode ver a força carregando nas costas a justiça, e o alto poder existindo só para os braços de maior bondade.

(ROSA, 1995, p. 249)

Es este el momento en el que la imaginación sociopolítica de Riobaldo supera por primera vez y definitivamente el ingenio de su antecesor Zé Bebelo. Riobaldo descubre una fuente infinita de poder en las masas, poder alimentado por un odio de carácter colectivo. Como si se tratara de un desfile fascista, Riobaldo ve a los catrumanos multiplicarse y avanzar sobre la ciudad. Los ve ocupando sus calles, desquitándose, haciendo que se les pague lo que se les debe, todas "las cosas buenas" de las que se han visto obligados a privarse. Los ve también responder a las privaciones a las que se han sometido con la destrucción y el caos. El principio de justicia, como retribución justa y reparadora de un daño inicial, se manifiesta en su comportamiento bajo la forma de la venganza. Ese odio, en suma, un 
verdadero pathos del resentimiento, proyección psicológica de infinidad de deseos frustrados, de ambiciones insatisfechas, se revela como un poder tremendamente subversivo.

Si el pensamiento de Riobaldo se limitara a esta constatación, no iría más allá del conocimiento que toda clase dominante tiene sobre los límites y los riesgos de la gobernabilidad. Su verdadero descubrimiento, sin embargo, consiste en comprender que esa energía puede ser canalizada, conducida, de modo que se convierta en agente del cambio social. Riobaldo va a encontrar en el resentimiento la variable más importante de una ecuación que le sirve como método para el desarrollo y la superación del atraso que los propios catrumanos representan. Es lo que hará efectivo cuando reclute a estos hombres para atravesar el desierto y después combatir contra las tropas de Hermógenes.

La fórmula descubierta por Riobaldo guarda cierta semejanza con las de los Estados políticos totalitarios que florecieron en todo el orbe en el período de entreguerras. Por más que Guimarães Rosa repudiara la lectura en clave exclusivamente histórica de sus textos de ficción, es difícil no ver en las páginas analizadas de Grande Sertão: Veredas asomos del modelo de modernización autoritaria que propusieran los totalitarismos del siglo XX, ya fuese en sus variantes nazista o fascista, ya fuese en la variante estalinista.

\section{CONCLUSIONES}

En Grande Sertão: Veredas hay cifrado un programa para el desarrollo y el crecimiento económico que requiere la instauración de un marco institucional y sociopolítico en el cual se protejan la propiedad y la inversión y al mismo tiempo se promuevan la inclusión social y el combate a la desigualdad y la pobreza. Riobaldo, héroe desarrollista al estilo de Fausto, es el líder que instaura y defiende tal marco al vencer a sus rivales con tácticas populistas y autoritarias.

Como suele suceder con las obras clásicas, la novela de Guimarães Rosa no cesa de sorprendernos por su indudable actualidad, al abordar cuestiones que son objeto de debate hoy por hoy en un contexto de crisis económica 
y de recesión global. Su lectura, por lo tanto, sigue siendo tan sugerente y cautivante en este momento como hace más de medio siglo.

\section{REFERÊNCIAS}

BERMAN, Marshall. Tudo o que é sólido desmancha no ar: a aventura da Modernidade. Tradução Carlos Felipe Moisés. São Paulo: Companhia das Letras. 1986.

BRAUDEL, Fernand. Civilização material, economia e capitalismo: séculos XV-XVIII. Vol. 3. O tempo do mundo. Tradução Telma Costa; revisão da tradução Monica Stahel. São Paulo: Martins Fontes, 1996.

KRUGMAN, Paul. The fall and rise of developing economics. In: Krugman, Paul. Development, Geography and Economic Theory. Cambridge, Massachusetts: The MIT Press, 1995. p. 1-29. Disponível em: <http://web.mit.edu/ krugman/www/dishpan.html>. Acesso em: 15 fev. 2014.

MANKIW, N. Gregory. Introdução à economia. Tradução Allan Vidigal Hastings, Elisete Paes e Lima. São Paulo: Cengage Learning, 2009.

ROSA, João Guimarães. Grande Sertão: Veredas. In: Ficção completa. Vol. II. Rio de Janeiro: Editora Nova Aguilar, 1995.

SAMUELSON, Paul A., William D. Nordhaus. Economia. Tradução Elsa Fontainha, Jorge Pires Gomes. 19 ed. Porto Alegre: AMGH, 2012.

SPENCE, Michael. Os desafios do futuro da economia: o crescimento econômico mundial nos países emergentes e desenvolvidos. Tradução Leonardo Abramowicz. Rio de Janeiro: Elsevier, 2011. 